\title{
Sustained Release Parenteral Dosage Form
}

National Cancer Institute

\section{Source}

National Cancer Institute. Sustained Release Parenteral Dosage Form. NCI Thesaurus.

Code C69036.

An injectable solution or suspension designed to release active and/or inert ing redient(s) slowly so as to achieve a constant circulating concentration of the ing redient over a period of time. 